This is the author's Post-print version (final draft post-refereeing as accepted for publication by the journal). The definitive, peer-reviewed and edited version of this article is published as: van Ham M. (2001) Workplace mobility and occupational achievement. International Journal of Population Geography 7, 295-306. http://dx.doi.org/10.1002/ijpg.225

\title{
Workplace mobility and occupational achievement
}

\section{Maarten van Ham}

Urban Research centre Utrecht (URU), Faculty of Geographical Sciences, Utrecht University, P.O. Box 80.115, 3508 TC Utrecht, The Netherlands. Phone: (31) 30 2531368. Fax: (31) 30 2532037. E-mail: m.vanham@geog.uu.nl

\begin{abstract}
This paper reports an investigation of the effects on occupational achievement of workplace mobility, that is, accepting a job over a longer distance. We extend the classical conceptualization of the relationship between spatial flexibility and occupational achievement by including not only long-distance migration, but also long-distance commuting as an instrument of career advancement. Using longitudinal data, with job change as the unit of analysis, career advancement is measured directly by comparing the level of the accepted job with the level of the former job. The results show that workplace mobility is indeed instrumental in career advancement. Workers who accept jobs over a longer distance make more career advancement after a job change than workers who accept jobs closer to their residence. Women with a partner form an exception. For them, workplace mobility has no effect on career advancement. A probable explanation is a tied-mover effect. Some women with a partner accept a job over a longer distance for the sake of the career of the male spouse and because the household as a whole migrates. So the conclusion is that for women workplace mobility is only instrumental in career advancement when a job is accepted over a long distance for one's own career.
\end{abstract}

Keywords: workplace mobility; job access; occupational achievement; career advancement; job level; gender; longitudinal data

\section{INTRODUCTION}

A high level of occupational achievement can hardly be obtained by staying in just one job. Instead, occupational achievement develops over the life course through job changes that are accompanied by career advancement. A job searcher faced with a lack of suitable job opportunities on the local labour market has to be spatially flexible to make career advancement through a job change. Workers who are prepared to broaden their search area can take advantage of job opportunities elsewhere and compete for more jobs (Mincer, 1978; Lichter, 1983; Markham and Pleck, 1986). The classical conceptualization of the relationship between spatial flexibility and occupational achievement is human capital related migration. Since Sjaastad's (1962) seminal article 'The costs and returns of human migration', longdistance migration is often referred to as a form of investment in human capital that is expected to pay for itself in the form of career advancement: increased income; better 
employment prospects; and/or higher occupational status (Sjaastad, 1962; Blau \& Duncan, 1967; Greenwood, 1975; see also Smits, 1999).

Over the past few decades, migration tolerance-people's willingness to migrate-has decreased, partly as a result of the rise in the share of dual-earner households. Dual-earner households have a lower propensity to migrate than couples or families with a single breadwinner (Mulder, 1993; Mulder and Hooimeijer, 1999; Jarvis, 1999), but may accept a longer commute. Long-distance commuting might therefore become an increasingly important substitute for migration. Measured in terms of distance, commuting tolerance has undoubtedly grown over the past few decades, through faster means of transport (Rouwendal \& Rietveld, 1994). Long-distance migration and commuting are both means of enlarging one's job search area.

This article describes a more comprehensive approach to the relationship between occupational achievement and spatial flexibility by looking not only at long-distance migration, but also at long-distance commuting. We use the concept of workplace mobility: accepting a job over a long distance from the residence (Van Ham et al., 2001c). Being prepared to commute over a long distance increases the probability of finding a better job quite as much as being prepared to migrate (see also Simpson, 1992). Stretching one's commuting tolerance by accepting a job over a longer distance can also be regarded as an investment in human capital.

The paper describes the instrumental nature of workplace mobility in career advancement: to what extent does accepting a job at a longer distance from the residence help? Answering this question with cross sectional data, comparing the job characteristics of those who have accepted a job over a long distance with those who have not, has the disadvantage that it is not possible to observe change at the individual level. For that, longitudinal data is needed. The data we have used come from a retrospective survey of aspects of life-event history of the Netherlands population conducted in 1993. A feature of our data is that it includes information on the complete labour market histories of the respondents. We use job change as the unit of analysis, which makes it possible to measure career advancement directly by comparing the level of the accepted job with the level of the former job.

\section{THEORY}

The theoretical framework commences with the relationship between job mobility and occupational achievement. Central in this conceptualization is human capital theory. Next, we place the relationship between job mobility and occupational achievement in a spatial context. What are the spatial determinants of career advancement? Finally, we include gender and the household context in the discussion.

\section{Job mobility, human capital and career advancement}

Job mobility is a prerequisite for career advancement. Changing jobs allows individuals to try out several jobs to ascertain their comparative advantages (Johnson, 1978); find higher quality job matches (Jovanovic, 1979); and achieve better pay (Parsons 1973; Burdett 1978). Job mobility allows individuals to take advantage of alternative job opportunities, thereby serving as a mechanism for upward social mobility (Lichter, 1983), or as a means of avoiding or reducing underemployment (Simpson, 1992).

Conceptually, job mobility is a cost which is instrumental in career advancement. Workers bear this cost in order to maximize the returns on their accumulated human capital 
(Becker, 1962). The stock of human capital people acquire during a lifetime has three main components. The first is general human capital, commonly acquired through the educational system, which enhances productivity equally in all sectors. The second is sector-specific human capital (Simpson, 1992). This human capital only enhances productivity in a particular sector of the economy. The third component is enterprise-specific human capital, which is acquired with tenure (on-the-job training) and is not transferable across employers. Sector and enterprise-specific human capital may be lost when workers change jobs. Assuming that workers want to maximize utility, we would expect all job changes to lead to career advancement. Since workers with substantial accumulated specific human capital have higher costs when they change jobs, we expected that when they did change jobs they would achieve more career advancement than was the case for the less well educated. The more highly educated simply cannot afford to change jobs without making a career advancement.

Research reveals a negative relationship between age and job mobility (Mincer, 1962; Van Ham et al., 2001c). The costs of a job change increase as age rises. Older workers have longer tenures and therefore more specific human capital. They also have fewer remaining years of work in which to recoup the costs of a job change. These high costs led us to expect that older workers only changed jobs when they could make a career advancement. We therefore anticipated a positive relationship between age and career advancement among those who do change jobs.

Workers who have not been employed for a substantial period of time may find that potential employers value their accumulated level of human capital less highly than that of workers who take a new job immediately after they leave their old one. This potential loss of human capital led us to expect a period of non-employment to have a negative influence on career advancement.

Finding a suitable job is more difficult in a period of economic recession, when the overall level of unemployment is high. In the Netherlands, registered unemployment increased from 0.9 percent in 1970 to almost 4 percent in 1979. In 1984, unemployment reached its highest point of more than 11 percent; in the early 1990s the rate decreased again to about 6 percent (CBS, 1999). We expected job changes taking place after the early 1970s to have led to less career advancement than those taking place in earlier years.

\section{Workplace mobility, job access and career advancement}

Career advancement through job mobility is only possible if suitable employment is available and accessible. The availability of employment opportunities largely depends on the spatial configuration of suitable employment relative to the location where one lives (see Van Ham et al., 2001a). In discussing job availability, the segmentation of the labour market should be taken into account. Workers differ in their level and degree of specialization of human capital and jobs differ by level. Only a subset of all the jobs within reach is suitable for an individual job searcher. Assuming that workers want to maximize the returns on previous investments in human capital, they will only consider jobs where this human capital can be maximized (see also Becker, 1962).

The accessibility of jobs is determined by the spatial flexibility of individual workers: migration and commuting tolerance. Workers' migration tolerance is limited because of the high costs of a residential move. People build up location specific capital and this inhibits spatial mobility (DaVanzo, 1981). Home ownership and family obligations come to mind, as do the high psychological costs of leaving familiar surroundings (Sjaastad, 1962; Polachek \& Hovarth, 1977). Most people's commuting tolerance is limited: for most employees, the maximum is 45 minutes' commuting (Wachs \& Taylor, 1993; Van Ommeren, 1996). In practice, Wachs \& Taylor (1993) find for the US that almost two thirds of all employees spend 
less than 35 minutes commuting to work. In the Netherlands, $80 \%$ of all employees spend half an hour or less (Van Ham et al., 2001a).

The effect of the availability and accessibility of jobs on career advancement is a wider issue that also plays a part in the spatial mismatch debate. The 'spatial mismatch hypothesis' as formulated by Kain (1968) was "originally coined to describe a broad set of geographical barriers to employment for African-American inner city residents" (Preston \& McLafferty, 1999: 387). It has, however, much to offer in a broader conceptualization of the relationship between space, distance and labour market outcomes for larger groups on the labour market. Central in the spatial mismatch debate is that poor geographical access to jobs reduces employment opportunities and negatively influences labour market outcomes. Kain has already acknowledged how space is connected and embedded in social structures and labour market processes and has described the importance of transportation in shaping access to employment (Preston \& McLafferty, 1999).

Our two main hypotheses derive from the discussion above. Since access to suitable local jobs increases the probability of finding a better job, we hypothesise that living on a location with good job access leads to more career advancement when people change jobs. Spatial mismatch research in the 1990s underwent major advances in the detailed measurement of geographical access to suitable employment using GIS (Hanson et al. 1997, Ong \& Blumenberg 1998, Van Ham et al., 2001a).

We further deduced from the spatial mismatch hypothesis that, if geographical barriers hamper individual labour careers, workplace mobility is instrumental in career advancement. Workplace mobility enables workers to take advantage of job opportunities elsewhere and provides the opportunity of competing for more jobs. The second, and main, hypothesis is thus that workplace mobility has a positive effect on career advancement.

\section{Gender, household and career advancement}

The presence of a working partner and the traditional division in many households of housekeeping and childcare responsibilities restricts women in their job search (see Van Ham et al., 2001b). There are several reasons for believing that the household context also restricts women in their occupational achievement. One of the reasons is that restricted search might lead to less optimal search outcomes, leading to less career advancement when changing jobs. In a household with two income providers, job search has to be optimized for two workers. According to the theory of differential over-qualification, this situation is almost incapable of resolution, so search is likely to be optimized for the main income provider, who is often the husband (Frank, 1978; Büchel, 1998). It is also possible that some women with spouses, particularly those with working spouses, place a low priority on pursuing a career (Van Ommeren, Rietveld \& Nijkamp, 1999). This attitude might also lead to less career advancement. Further, women, and especially women with children, are over represented in the supplementary labour market. These jobs are often low paid, part-time and with little security, and so offer few career opportunities (Droogleever-Fortuijn, 1993; Hanson \& Pratt, $1988 ; 1990 ; 1991)$. We therefore expected that, for women changing jobs, having a partner and children leads to less career advancement.

Gender was also expected to have an effect on the relationship between availability and accessibility of employment opportunities and career advancement. In the literature, two gender related aspects of the effect of geography on career advancement prevail. The first is that the job search areas of men and women differ in size. Men tolerate longer commuting times than women (Madden, 1981; Gordon et al., 1989; Turner \& Niemeijer, 1997). Further, research by Van Ham et al. (2001c) has revealed that women show less workplace mobility than men. According to Madden (1981), gender differences in household roles strongly 
influence women to accept jobs closer to home (see also Johnston-Anumonwo, 1992, on the household responsibility hypothesis). Because women are more spatially restricted, we expected that for women access to suitable local employment has a stronger effect on career advancement than for men.

The second aspect is that research reveals an exception to the rule that workplace mobility helps career advancement. In the case of job related migration, the rule only applies to individuals who migrate for their own career. It is a different story for people who migrate for the sake of somebody else's career (Smits, 1999). For these tied movers, migration can be expected to have a negative effect on occupational achievement (Mincer, 1978; Bielby \& Bielby, 1992). In many households the husband is still the main income provider, so most long-distance moves take place for the sake of his career (Markham \& Pleck, 1986; Bonney \& Love, 1991). Most tied movers are therefore women who migrate along with their male partners (Shihadeh, 1991). We therefore expected that, for women with a partner, workplace mobility leads to less career advancement than for single women.

\section{DATA AND METHODS}

The data were taken from the Netherlands SSCW survey ${ }^{1}$. This retrospective survey was conducted in 1993 with a sample population of some 3000 members of about 1600 households. The sample of this retrospective survey is representative of the Netherlands population aged 18 and over in the beginning of the 1990s. Respondents answered questions on a wide variety of topics in several rounds. This procedure led the response level to vary between the topics; some respondents left or entered the sample during the survey period. The set contains data about the respondents' residential, educational, household, and labour market histories.

Since our interest lies in the influence of workplace mobility on change in job level, the unit of analysis chosen was a job change. We excluded first jobs, since a change in job level can only be observed if people have had at least two jobs. After selection on the number of hours worked (at least 12 hours a week) and missing values, the data set contained 4,436 job changes. The 868 men in the data set changed jobs 2,743 times (average 3.2 job changes per male respondent) and the 668 women changed jobs 1,693 times (average 2.5 job changes per female respondent). We estimated separate models for men and women.

More than one job change per individual might enter the analyses, thereby violating the standard assumption of the independence of observations. This clustering of data can be handled by using multilevel models. Our model has two levels: the level of the job change and the individual level. We estimated a random effects model in which the intercept was assumed to vary randomly across workers. The model specification is given in the Appendix.

We sought a model of career advancement: the difference in job level between the former job and the newly accepted job. Using the difference between the job level score of the accepted and former jobs as the dependent variable is not an advisable strategy, because there is a negative correlation between the job level of the former job and the change in job level (see also Markus, 1979). We therefore used the job level of the accepted job as the dependent variable and included the level of the former job as an independent variable. By doing this, the effects of the other independent variables can be interpreted as their effect on the change in job level (Johnson, 1988).

Despite the advantage of including job level of the former job as an independent variable it also has a major disadvantage: it violates one of the standard assumptions underlying the use of a random effects model. The random effects model assumes the error 
terms at the job level and at the individual level to be uncorrelated. Because we use information about the previous job belonging to the same person, unmeasured characteristics of that person undoubtedly cause part of the effect we measure; our estimate is subject to omitted variable bias. So, in our model it is very likely that job level of the former job is correlated with the person specific component of the error term $u_{j}$ (see appendix for model specification).

To test to what extent our approach produces biased parameter estimates we compared the estimates resulting from the random effects model (GLS) with those resulting from a fixed effects model (OLS) which produces more conservative estimates (see Jones and Bullen, 1994). The fixed effects model allows each individual to have an independent intercept. By including a series of dummies representing the individual workers in the data set, unobserved individual characteristics are controlled for. The advantage is that all of the explanatory variables can be correlated with the person-specific component of the error term $\mathrm{u}_{\mathrm{j}}$, while the fixed effects estimator is still consistent. The only practical problem with this technique is that it is costly in terms of losing degrees of freedom.

\section{Dependent variable}

The dependent variable of job level is as developed by Conen \& Huijgen (1980). They assigned skill levels to jobs on the basis of the classification of occupations by Statistics Netherlands (BRC-84). Skill levels are defined by training time, autonomy, and the amount of theoretical or practical schooling needed to perform the task adequately. Seven levels are distinguished, ranging from unskilled work (level 1) to specialized work at an academic level (level 7). Strictly, the measurement level of the dependent variable is ordinal, but it can be assumed that the variable approaches the interval level sufficiently (Huijgen et al., 1983).

\section{Independent variables}

Besides the job level of the former job, 9 other independent variables enter the models. Age at the moment of accepting the job is measured in years. To control for non-linearity of the age effect, both a linear and a quadratic term of the age variable is included. Level of education is measured in five categories: primary education; lower-level secondary education; upper-level secondary education; higher vocational education; university. The presence of a partner at the moment of accepting a job is measured by a dummy. The presence and age of children at the moment of accepting a job is recorded in four categories: no children; youngest child under 5 years old; youngest child between 5 and 10 years old; youngest child between 10 and 15 years old. The period in which the job was accepted is classified according to the following four categories: $1950-1959 ; 1960-1969 ; 1970-1979 ; 1980-1992$. Whether or not there was a period of non-employment of at least 1 year between the accepted and the former job is measured by a dummy variable.

Another dummy is used to indicate workplace mobility: whether or not the job was accepted over a long distance. We defined long distance as 45 kilometres or more, which is equivalent to some 30-40 minutes of travel time (Van Ham et al., 2001c). This is a reasonable approximation of the maximum time people are willing to commute. For all job changes, we calculated the distance between the place of residence one year before the interview and the location of the accepted job: this is the distance over which workers accepted a job.

Access to suitable employment from the residential location one year before accepting the job is measured as the number of jobs, by job level, which can be reached within 30 minutes by car over the transport network (see Van Ham et al., 2001a, for a detailed description of the method used). The measure of job access is calculated with the GIS extension Flowmap (De Jong \& Floor, 1993). We allotted a measure of job access to all the 
job changes on the basis of the municipality of residence one year before accepting the job. The data on job opportunities were derived from the National Information System of Employment $^{2}$ (LISA 1991 and 1994) and the Netherlands labour force survey (EBB 1994, 1995, 1996) conducted by Statistics Netherlands.

\section{RESULTS}

Just over 18 percent of all job changes in our data set led to a decrease in job level; in 53 percent the level of the job did not change; and 29 percent of the changes led to an increase in job level. There were no significant differences between men and women in this respect. With regard to workplace mobility, more than 15 percent of all jobs were accepted over a long distance from the residence. As expected, for men the proportion of jobs accepted over a long distance is higher than for women (18 and 11 percent respectively).

Table 1 shows the impact of the explanatory variables on the level of the accepted job. Because the job level of the former job has also been entered in the analyses, other parameter estimates can be interpreted as effects on career advancement: the change in job level. To test to what extent this approach produces biased parameter estimates in a random effects model (GLS), we compared the estimates with those resulting from a fixed effects model (OLS).

We did not find large differences between the random effects and fixed effects estimates. The effect of workplace mobility - the main independent variable - appeared to be even more significant in the more conservative fixed effects model. We are therefore confident only to show the random effects estimates. Further, the random effects estimates are preferred because they are more efficient-they use both the within-person and between-person variation.

There is, however, one main difference between the random effects and fixed effects estimates, which is worth discussing. As expected, in the random effects model for both men and women the level of the former job has a positive effect on the level of the accepted job. In the fixed effects model, however, for men, the effect of the level of the former job level is still positive and significant, but much smaller. For women the effect is not even significant. This finding is not surprising since using a fixed effects model is known for decreasing the probability of omitted variable bias: level of the former job captures a lot of unobserved characteristics of the individual worker.

Career advancement is related non-linearly to worker's age. As expected, with increasing age the extent to which workers make career advancement through a job change first rises and subsequently falls. Men are estimated to reach the top of their careers at the age of 56 and women at the age of 47. A possible explanation of this non-linear effect might be that older workers at the end of their labour career do not always change jobs to make a career advancement. Since they are already at the top of their careers, they might change jobs for other reasons, for example to a job at the same level, but closer to home.

Level of education is positively related to career advancement. Women with a university degree form an exception; they make less career advancement than women with higher vocational education.

As expected, for women, the presence of children in the household has a negative effect on career advancement. Contrary to what was expected however, women with older children make less career advancement than women with younger children. Also as expected, for women the presence of a partner has a negative effect on career advancement. For men, the presence of children and partner has no effect on career advancement. These results confirm the hypothesised gendered effect of the household context. 
More than 25 percent of those who accepted a job after a period of non-employment experienced a decrease in job level, compared with 17 percent of those who took a new job immediately on leaving the old one. The multivariate results in table 1 show that a period of non-employment of at least 1 year between the accepted and the former job does indeed have a negative effect on career advancement. This effect is much stronger for women than for men. Apparently, women lose more of their accumulated human capital in a period of nonemployment.

As expected, workers who accepted a job after 1970 made less career advancement than those who accepted a job before 1970. This can be explained by the fact that the level of registered unemployment in the Netherlands increased markedly from 1970 onwards. We found a smaller effect for intervening period for women than for men.

We hypothesised that workers who live on locations with good access to suitable employment make more career advancement than workers who live on locations with poor job access. Although the parameters of job access were in the right direction, we did not find that job access had a significant effect on career advancement for either men or women. The selectivity of those who change jobs might explain the absence of a job access effect. Van Ham and Mulder (1999) showed that job access has a positive influence on occupational achievement measured in a static way: workers who live on locations with good job access reach higher job levels. Workers with higher level jobs change jobs less often to make career advancement. Further, people with really poor job access participate less on the labour market and are less engaged in job search; this poorer access also leads to reduced job mobility (see Van Ham et al., 2001b). The job access related selective nature of job mobility might explain why we did not find any extra effect of job access on career advancement in addition to the known effect of job access on occupational achievement.

The central hypothesis is that workplace mobility is instrumental in career advancement. Workplace mobility enables workers to take advantage of job opportunities elsewhere and provides the opportunity of competing for more jobs. As expected, workplace mobility has a positive effect on career advancement for men. Men who accepted a job over a longer distance make more career advancement than those who accept jobs closer to their residence. We did not find an effect of workplace mobility for women.

\section{Table 1. Multilevel model regression model of change in job level}

We hypothesised a gendered effect of workplace mobility for workers with a partner. We expected workplace mobility to have a smaller effect on career advancement for women with a partner than for single women: women with a partner are often tied movers. No significant differences were expected for men. We estimated two more models to investigate whether there was an interaction effect between workplace mobility and having a partner. We included a variable in the form of three dummies to measure whether a job was accepted over long distance, with, or without a partner. The reference category is those workers with a partner who did not accept a job over a longer distance. These workers were expected to make the least career advancement when changing jobs. The results in table 2 confirm that for men workplace mobility has a positive effect on career advancement. Men with a partner who accepted a job over a longer distance have the highest probability of making career advancement. For women, the picture is quite different. For them, workplace mobility is only instrumental in career advancement when they are single; that is to say, when they accept a job over a longer distance for the sake of their own careers. The absence of an effect of workplace mobility for women with a partner suggests the existence of a tied mover effect. 
Table 2. Multilevel model of change in job level with interaction effect

\section{DISCUSSION}

Our goal in this contribution has been to extend our understanding of the relationship between spatial flexibility and occupational achievement. Our analyses contribute to the existing literature in two ways. The first of these is our use of the concept of workplace mobility: accepting a job over a longer distance. This approach is more comprehensive than the traditional one, because we include both long-distance migration and long-distance commuting as an instrument in career advancement. Long-distance commuting is becoming increasingly important, because the migration tolerance of households has decreased through the dramatic increase in the number of two earner and two career households in recent years. From our point of view, both forms of accepting a job over a long distance may be regarded as an investment in human capital.

Our second contribution is that we have measured career advancement directly by comparing the level of the accepted job with the level of the former job. A feature of our data is that it includes the complete labour market histories of the respondents. Using this longitudinal data makes it possible to take job change as the unit of analysis.

The starting point of our conceptualization is that career advancement through job mobility is only possible if suitable employment is available and accessible. We expected workers with access to a large set of suitable employment opportunities to make more career advancement than other workers. We further expected workplace mobility to be instrumental in career advancement, because it gives workers the opportunity to compete for more jobs. A critical note regarding the influence of workplace mobility on career advancement might be useful here. It is likely that people who are motivated do better in their careers and also accept jobs over a longer distance. If this is the case, one could discuss to what extent a positive association between workplace mobility and occupational achievement can be interpreted as being the effect of the former on the latter. However, as indicated in the theoretical part of this paper, conceptually, workplace mobility is a cost which is instrumental in career advancement. Workplace mobility is therefore not the cause of career advancement, but an instrument that leads to career advancement. Obviously, more motivated workers will more often use this instrument, but this does not change the instrumental nature of workplace mobility, and one may still state that workplace mobility helped to advance the careers of these motivated workers.

Contrary to what was expected, we did not find an effect of job access on career advancement. A possible explanation is the selectivity of those who change jobs. Van Ham and Mulder (1999) showed that job access has a positive effect on the job level workers reach, measured in a static way. Workers with higher level jobs change jobs less often to make career advancement. This selective nature of job mobility might explain why we did not find an extra effect of job access on career advancement in addition to the effect on the level of the job in general. Another explanation might be that the inclusion of the context variable job access may not have been optimal. Other variables, for example the number of suitable vacancies that can be reached, might measure the local opportunity set of job opportunities in a better way. Data on vacancies might also offer better opportunities for operationalizing suitability; in our data, the level of the jobs within reach is the only measure for suitability. More tailored measures of job access modelling might strengthen the analyses of the role of job access in career advancement. Unfortunately, data on vacancies is seldom available and usually of questionable reliability. 
The analyses confirmed our expectations regarding the instrumental nature of workplace mobility in career advancement. Workers who accept a job over a longer distance make more career advancement than workers who accept jobs closer to their residence. However, the analyses also confirmed that women with a partner form an exception to the rule. For them, workplace mobility has no effect on career advancement. A probable explanation is a tied-mover effect. Some women with a partner accept a job over a longer distance for the sake of the career of the male spouse, because the household as a whole migrates. The conclusion is that, for women, workplace mobility is only instrumental in career advancement when jobs are accepted over a long distance for their own careers.

\section{ACKNOWLEDGEMENTS}

Maarten van Ham's research was supported by the Netherlands Organisation for Scientific Research (grant nr.42513002). I am grateful to Clara H. Mulder and Pieter Hooimeijer from the Urban Research centre Utrecht (URU) for their valuable comments on earlier versions of this paper. I am especially grateful to Clara H. Mulder for her help with preparing the data. Further, I would like to thank Nathan Jensen, Tim Schwanen and the anonymous referees for their insightful comments regarding the use of a fixed effects model to test to what extent the random effects model produced biased estimates.

\section{NOTES}

(1) The survey was commissioned by the Stichting Sociaal-culturele Wetenschappen (SSCW), Nederlandse Organisatie voor Wetenschappelijk onderzoek (NWO). The data set is available under the title 'Aspects of life-event history of the Dutch population: part 1: changes in socio-demographic data, social mobility, relationships history, educational career, and work mobility' at the Niwi Steinmetz archives (under number P1107).

(2) The LISA datasets were obtained from the RIVM for the Ruimtescanner project.

\section{REFERENCES}

Becker G. 1962. Human capital: a theoretical and empirical analysis. Journal of Political Economy 70: 9-46.

Bielby WT, Bielby DD. 1992. I will follow him: family ties, gender-role beliefs, and reluctance to relocate for a better job. American Journal of Sociology 97:1241-1267.

Blau PM, Duncan OD. 1967. The American Occupational Structure. Wiley: New York.

Bonney N, Love J. 1991. Gender and migration: geographical mobility and the wife's sacrifice. The Sociological Review 39: 335-348.

Burdett K. 1978. A theory of employee job search and quit rates. American Economic Review 68: $212-220$.

Büchel F. 1998. Zuviel gelernt? Ausbildungsinadäquate Erwerbstätigkeit in Deutschland (Learned too much? Overeducation in Germany). W. Bertelsman Verlag: Bielefeld.

CBS. 1999. Statline. Centraal Bureau voor de Statistiek: Voorburg/Heerlen. 
Conen GJM, Huijgen F. 1980. De kwalitatieve structuur van de werkgelegenheid in 1960 en 1971. Deel I (The qualitative structure of the labour market in 1960 and 1971. Part I). Economisch-Statistische Berichten April: 480-487.

DaVanzo J. 1981. Microeconomic approaches to studying migration decisions. In Migration decision making. Multidisciplinary approaches to microlevel studies in developed and developing countries, De Jong GF, Gardner RW (eds.); Pergamon Press: New York; 90129.

De Jong T, Floor H. 1993. Flowmap: een programma voor het weergeven en analyseren van interactiegegevens (Flowmap: a software package for displaying and analysing interaction data). Planning, methodiek en toepassing 44: 16-31

Droogleever Fortuijn JC. 1993. Een druk bestaan: tijdbesteding en ruimtegebruik van tweeverdieners met kinderen (A busy life: the use of time and space in dual-earner families). Amsterdam University Press.

Frank RH. 1978. Why women earn less: the theory and estimation of differential overqualification. The American Economic Review 68: 360-373.

Gordon P, Kumar A, Richardson HW. 1989. Gender differences in metropolitan travel behaviour. Regional Studies 23: 499-510.

Greenwood MJ. 1975. Research on internal migration in the United States: a survey. Journal of Economic Literature 13: 397-433.

Hanson S, Pratt G. 1988. Spatial dimensions of the gender division of labour in a local labour market. Urban Geography 9: 180-202.

Hanson S, Pratt G. 1990. Geographic perspectives on the occupational segregation of woman. National Geographic Research 6: 376-399.

Hanson S, Pratt G. 1991. Job search and the occupational segregation of women. Annals of the Association of American Geographers 81: 229-253.

Hanson S, Kominiak T, Carlin S. 1997. Assessing the impact of location on women's labor market outcomes: a methodological explanation. Geographical Analysis 29: 281-297.

Huijgen F, Riesewijk, BJP, Conen GJM. 1983. De kwalitatieve structuur van de werkgelegenheid in Nederland. Bevolking in loondienst en functieniveaustructuur in de periode 1960-1977 (The qualitative structure of the labour market in The Netherlands. Employees and job level structure in the period 1960-1977). Staatsuitgeverij: Den Haag.

Jarvis H. 1999. Identifying the relative mobility prospects of a variety of household employment structures, 1981-1991. Environment and Planning A 31: 1031-1046.

Johnson DR. 1988. Panel analysis in family studies. Journal of Marriage and the Family 50: 949-955.

Johnson WR. 1978. A theory of job shopping. Quarterly Journal of Economics 92: 261-277.

Johnston-Anumonwo I. 1992. The influence of household type on gender differences in work trip distance. Professional Geographer 44: 161-169.

Jones K, Bullen N. 1994. Contextual models of urban house prices: a comparison of fixedand random-coefficient models developed by expansion. Economic Geography 70: 252272.

Jovanovic B. 1979. Job matching and the theory of turnover. Journal of Political Economy 87: 972-990.

Kain J. 1968. Housing segregation, Negro employment, and metropolitan decentralization. Quarterly Journal of Economics 82: 175-197.

Lichter DT. 1983. Socioeconomic returns to migration among married women. Social Forces 62: 487-503.

Madden JF. 1981. Why women work closer to home. Urban Studies 18: 181-194. 
Markham WT, Pleck JH. 1986. Sex and willingness to move for occupational advancement: some national sample results. Social Science Quarterly 27: 121-143.

Markus GB. 1979. Analyzing panel data. Sage University Paper series / Number 07-018, Sullivan JL (ed.); Sage Publications: Beverly Hills/London.

Mincer J. 1962. On the job training: costs, returns, and some implications. Journal of Political Economy 70: 50-79.

Mincer J. 1978. Family migration decisions. Journal of Political Economy 86: 749-773.

Mulder CH. 1993. Migration dynamics: a life course approach. Thesis Publishers, Amsterdam.

Mulder CH, Hooimeijer P. 1999. Residential relocations in the life course. In Population Issues. An interdisciplinary focus, Wissen LJG, Dykstra PA (eds.); Kluwer Academic/Plenum Publishers: New York; 159-186.

Ong P, Blumenberg E. 1998. Job access, commute, and travel burden among welfare recipients. Urban Studies 31: 77-93.

Parsons DO. 1973. Quit rates over time: a search and information approach. American Economic Review 63: 390-401.

Polachek SW, Horvath FW. 1977. A life cycle approach to migration: analysis of the perspicacious peregrinator. In Research in labor economics: an annual compilation of research (volume 1), Ehrenberg RG (ed.); JAI Press: Greenwich, Connecticut; 103-150.

Preston V, McLafferty S. 1999. Spatial mismatch research in the 1990s: progress and potential. Papers in Regional Science 78: 387-402.

Rasbash J, Browne W, Goldstein H, Yang M, Plewis I, Healy M, Woodhouse G, Draper D, Langford I, Lewis T. 2000. A user's guide to MlwiN, version 2.1. Multilevel Models Project, Institute of Education, University of London.

Rouwendal J, Rietveld P. 1994. Changes in commuting distances of Dutch households. Urban Studies 31: 1545-1557.

Shihadeh ES. 1991. The prevalence of husband-centered migration: employment consequences for married mothers. Journal of Marriage and the Family 53: 432-444.

Simpson W. 1992. Urban structure and the labour market: worker mobility, commuting and underemployment in cities. Clarendon Press: Oxford.

Sjaastad LA. 1962. The costs and returns of human migration. Journal of Political Economy 70: $80-93$.

Smits J. 1999. Family migration and the labour-force participation of married women in the Netherlands, 1977-1996. International Journal of Population Geography 5: 133-150.

Turner T, Niemeier DA. 1997. Travel to work and household responsibility: new evidence. Transportation 24: 397-419.

Van Ham M., Mulder CH. 1999. De regionale component in de afstemming tussen opleiding en functieniveau (Regional differences in the match between education and job level). Mens en Maatschappij 74: 392-406.

Van Ham M, Hooimeijer P, Mulder CH. 2001a. Urban form and job access: disparate realities in the Randstad. Forthcoming in Tijdschrift voor Economische en Sociale Geografie 92.

Van Ham M, Mulder CH, Hooimeijer P. 2001b. Local underemployment and the discouraged worker effect. Urban Research centre Utrecht working paper, manuscript submitted to journal.

Van Ham M, Mulder CH, Hooimeijer P. 2001c. Spatial flexibility in job mobility: macro-level opportunities and micro-level restrictions. Forthcoming in Environment and Planning A.

Van Ommeren J. 1996. Commuting and relocation of jobs and residences: a search perspective. Vrije Universiteit Amsterdam. 
Van Ommeren J, Rietveld P, Nijkamp P. 1999. Impacts of employed spouses on job-moving behaviour. International Regional Science Review 22: 54-68.

Wachs M, Taylor BD. 1993. The changing commute: a case study of the jobs-housing relationship over time. Urban Studies 30: 1711-1730.

\section{APPENDIX}

The multilevel model is specified as follows. Let $y_{i j}$ be the level of the accepted job for the $i$ th job change for the $j$ th worker. Then the model is written as:

where

$$
y_{i j}=\beta_{0 i j}+\beta_{1} x_{1 i j}+\ldots
$$

$$
\beta_{0 i j}=\beta_{0}+u_{j}+e_{i j}
$$

This model is a socalled random effects model, in which the intercept is assumed to vary randomly across workers and jobs, but where the relationship between the dependent and the independent variables is assumed to be the same for all job changes within workers. Both $u_{j}$ and $e_{i j}$ are random quantities, whose means are equal to zero; they form the random part of the model. We assume that, being at different levels, these variables are uncorrelated and we further make the standard assumption that they follow a normal distribution so that it is sufficient to estimate their variances, $\sigma_{u}^{2}$ and $\sigma^{2}$ respectively (Rasbash et al., 2000). The quantities $\beta_{0}$ and $\beta_{1}$, the mean intercept and slope, are known as fixed parameters. The estimation was done using MLwiN. 
Table 1. Multilevel model regression model of change in job level

$\begin{array}{lll}\text { Men model } 1 & \text { Women model } 1 \\ \text { B } & \text { s.e. } & \text { B }\end{array}$

\begin{tabular}{|c|c|c|c|c|c|c|}
\hline Job level former job (level 1 to 7$)^{\mathrm{a}}$ & 0.411 & 0.018 & $* * *$ & 0.420 & 0.022 & $* * *$ \\
\hline Age (in years) ${ }^{\mathrm{a}}$ & 0.092 & 0.019 & $* * *$ & 0.107 & 0.022 & $* * *$ \\
\hline Age $(\text { squared })^{\mathrm{a}}$ & -0.001 & 0.000 & $* * *$ & -0.001 & 0.000 & $* * *$ \\
\hline \multicolumn{7}{|l|}{ Education $(\text { primary }=0)^{\mathrm{b}}$} \\
\hline low secondary ${ }^{\mathrm{b}}$ & 0.489 & 0.097 & $* * *$ & 0.434 & 0.095 & $* * *$ \\
\hline upper secondary ${ }^{\mathrm{b}}$ & 0.909 & 0.107 & $* * *$ & 0.760 & 0.112 & $* * *$ \\
\hline high vocatonal $^{\mathrm{b}}$ & 1.292 & 0.115 & $* * *$ & 1.460 & 0.134 & $* * *$ \\
\hline University $^{\mathrm{b}}$ & 1.626 & 0.014 & $* * *$ & 1.228 & 0.167 & $* * *$ \\
\hline \multicolumn{7}{|l|}{ Children $(\text { no children }=0)^{\mathrm{a}}$} \\
\hline Child $0-5^{\text {a }}$ & 0.055 & 0.072 & & -0.100 & 0.114 & \\
\hline Child 6-10 & 0.002 & 0.102 & & -0.216 & 0.120 & $*$ \\
\hline Child $11-15^{\mathrm{a}}$ & -0.188 & 0.134 & & -0.443 & 0.134 & $* * *$ \\
\hline Partner $^{\mathrm{a}}$ & 0.031 & 0.069 & & -0.163 & 0.066 & $* * *$ \\
\hline Period of unemployment ${ }^{\mathrm{a}}$ & -0.180 & 0.088 & $* *$ & -0.377 & 0.086 & $* * *$ \\
\hline \multicolumn{7}{|l|}{ Period $(1950-1959=0)^{\mathrm{a}}$} \\
\hline Period $1960-1969^{\mathrm{a}}$ & -0.070 & 0.080 & & -0.038 & 0.088 & \\
\hline Period $1970-1979^{a}$ & -0.206 & 0.080 & $* * *$ & -0.054 & 0.088 & \\
\hline Period $1980-1992^{\mathrm{a}}$ & -0.245 & 0.081 & $* * *$ & -0.160 & 0.095 & $*$ \\
\hline Job access (millions of jobs) ${ }^{\mathrm{a}}$ & 0.121 & 0.077 & & 0.016 & 0.085 & \\
\hline Workplace mobility $^{\mathrm{a}}$ & 0.266 & 0.064 & $* * *$ & 0.066 & 0.084 & \\
\hline Constant & -0.031 & 0.031 & & -0.013 & 0.326 & \\
\hline Variance job change level & 0.152 & 0.029 & $* * *$ & 0.131 & 0.030 & $* * *$ \\
\hline Variance worker level & 1.318 & 0.042 & $* * *$ & 0.962 & 0.040 & $* * *$ \\
\hline
\end{tabular}

$* p<0.10, * * p<0.05, * * * p<0.01$

${ }^{\mathrm{a}}$ Variable at job level

${ }^{\mathrm{b}}$ variable at worker level 
Table 2. Multilevel model of change in job level with interaction effect Men model 2

B

s.e.

Women model 2

Job level former job (level 1 to 7$)^{\mathrm{a}}$

$0.411 \quad 0.018$

$0.092 \quad 0.019$

$* * *$

B

s.e.

Age (in years) ${ }^{\mathrm{a}}$

$-0.001 \quad 0.000$

$* * *$

0.418

0.022

$0.105 \quad 0.022$

Age (squared) ${ }^{\mathrm{a}}$

$0.486 \quad 0.097$

$-0.001$

0.000

Education (primary $=0)^{\mathrm{b}}$

low secondary ${ }^{b}$

0.904

0.107

$* * *$

0.437

0.095

upper secondary ${ }^{\mathrm{b}}$

1.288

0.116

$* * *$

0.767

0.112

high vocatonal $^{\text {b }}$

1.621

0.144

$* * *$

1.465

0.134

University

$0.053 \quad 0.072$

$* * *$

1.237

0.168

Children (no children $=0)^{a}$

Child $0-5^{\text {a }}$

0.001

0.102

$-0.101$

0.114

$-0.193 \quad 0.135$

$-0.219$

0.120

Child 11-15

$-0.181 \quad 0.088$

$-0.442$

0.134

Period of unemployment ${ }^{\mathrm{a}}$

$* *$

$-0.375$

0.086

Period $(1950-1959=0)^{a}$

Period 1960-1969 ${ }^{\mathrm{a}}$

$-0.071 \quad 0.080$

$\begin{array}{ll}-0.036 & 0.088 \\ -0.050 & 0.089\end{array}$

Period 1970-1979a

$-0.206 \quad 0.080$

$-0.036$

$-0.245 \quad 0.081$

$* * *$

$-0.050$

0.089

$0.119 \quad 0.077$

$-0.157$

0.095

Job access (millions of jobs) ${ }^{\mathrm{a}}$

0.015

0.085

(No workplace mobility with partner $=0$ )

No workplace mobility without partner ${ }^{\mathrm{a}}$

Workplace mobility with partner ${ }^{\mathrm{a}}$

$\begin{array}{ll}-0.019 & 0.073\end{array}$

$* * *$

0.141

0.069

$0.256 \quad 0.081$

$* * *$

$-0.022$

0.116

0.162

0.109

0.301

0.128

Constant

$\begin{array}{ll}-0.007 & 0.337\end{array}$

$-0.134$

0.350

$\begin{array}{ll}0.151 & 0.029\end{array}$

$* * *$

0.134

0.030

1.318

0.041

0.958

0.040

$* * *$

$* p<0.10, * * p<0.05, * * * p<0.01$

${ }^{\mathrm{a}}$ Variable at job level

${ }^{\mathrm{b}}$ variable at worker level 